\title{
Polyurethane/fluor-hydroxyapatite nanocomposite scaffolds for bone tissue engineering. Part I: morphological, physical, and mechanical characterization
}

\author{
This article was published in the following Dove Press journal: \\ International Journal of Nanomedicine \\ 5 January 2011 \\ Number of times this article has been viewed
}

\author{
Azadeh Asefnejad' \\ Aliasghar Behnamghader ${ }^{2}$ \\ Mohammad Taghi \\ Khorasani ${ }^{3}$ \\ Babak Farsadzadeh' \\ 'Department of Biomedical \\ Engineering, Science and Research \\ Branch, Islamic Azad University, \\ Tehran, Iran; ${ }^{2}$ Materials and Energy \\ Research Center, Tehran, Iran; ${ }^{3}$ Iran \\ Polymer and Petrochemical Institute, \\ Tehran, Iran
}

\begin{abstract}
In this study, new nano-fluor-hydroxyapatite (nFHA)/polyurethane composite scaffolds were fabricated for potential use in bone tissue engineering. Polyester urethane samples were synthesized from polycaprolactone, hexamethylene diisocyanate, and 1,4-butanediol as chain extender. Nano fluor-hydroxyapatite (nFHA) was successfully synthesized by sol-gel method. The solid-liquid phase separation and solvent sublimation methods were used for preparation of the porous composites. Mechanical properties, chemical structure, and morphological characteristics of the samples were investigated by compressive test, Fourier transform infrared, and scanning electron microscopy (SEM) techniques, respectively. The effect of nFHA powder content on porosity and pore morphology was investigated. SEM images demonstrated that the scaffolds were constituted of interconnected and homogeneously distributed pores. The pore size of the scaffolds was in the range 50-250 $\mu \mathrm{m}$. The result obtained in this research revealed that the porosity and pore average size decreased and compressive modulus increased with nFHA percentage. Considering morphological, physical, and mechanical properties, the scaffold with a higher ratio of nFHA has suitable potential use in tissue regeneration.
\end{abstract}

Keywords: polyester urethane, composite, fluor-hydroxyapatite, scaffold

\section{Introduction}

It is estimated that more than 500,000 bone graft procedures are performed per year in the United States alone. ${ }^{1}$ According to the high frequency of bone-grafting, the quantity of donor tissue is limited. ${ }^{1,2}$ These limitations have resulted in significant attention to alternative approaches such as bone tissue engineering. Bone tissue-engineered grafts require three main elements: 3-dimensional porous scaffolds, progenitor or mature cells, and appropriate growth factors. ${ }^{3}$

Biodegradable polymers are widely used as porous scaffold in bone tissue engineering. ${ }^{4}$ Biodegradable polyurethane is one of the most biocompatible materials used as temporary extracellular matrices in bone tissue engineering scaffolds. ${ }^{5,6}$ However, the major concern associated with biodegradable polyurethane is the lack of bioactive groups, which limits their applications. ${ }^{6}$ One solution is blending the polyurethanes with bioactive ceramic particles such as tricalcium phosphate or hydroxyapatite (HA). ${ }^{6-10}$ A combination of ceramic and polyurethane could improve bioactivity and enhance the mechanical properties of porous scaffolds. ${ }^{11}$

$\mathrm{HA}\left(\mathrm{Ca}_{10}\left(\mathrm{PO}_{4}\right)_{6}(\mathrm{OH})_{2}\right)$ has attracted much interest as an implant material for teeth and bones due to the similarity of its crystallography and chemical composition to
Correspondence: Azadeh Asefnejad Department of Biomedical Engineering, Science and Research Branch, Islamic Azad University, Tehran, Iran

Tel +98 9122795546

Fax +98 2I 44474319

Email asefnejad_azadeh@yahoo.com 
that of human hard tissues. ${ }^{12,13}$ In most cases, the controlled solubility of HA is an important factor, since it induces bioactivity, osteoconductivity, and therapeutic effects. On the other hand, pure fluorapatite (FA) with a chemical formula, $\mathrm{Ca}_{10}\left(\mathrm{PO}_{4}\right)_{6}(\mathrm{~F})_{2}$ is thought to have a much lower solubility than HA due to greater chemical and structural stability. ${ }^{14}$ Moreover, the FHA forms $\left(\mathrm{Ca}_{10}\left(\mathrm{PO}_{4}\right)_{6}(\mathrm{OH}, \mathrm{F})_{2}\right)$ solid solutions with $\mathrm{HA}$ by the replacement of $\mathrm{OH}^{-}$by $\mathrm{F}^{-}$. Hence, modulation of the extent of fluoride substitution provides an effective way of controlling the solubility of the apatite. In addition, $\mathrm{F}^{-}$enhances the mineralization and crystallization of calcium phosphate compounds during the bone regeneration. ${ }^{15,16}$ Also, FHA would facilitate joining between the implants and bone tissue because of its chemical similarity to the calcium phosphate parts in the bone tissue, and its ability to form a strong chemical bond with bone. In addition, FHA keeps comparable biocompatibility and bioactivity with pure HA in terms of the tissue and cell response..$^{17,18}$

The HA powder has been synthesized over the past years using different techniques, such as precipitation, hydrothermal, and sol-gel methods. ${ }^{19}$ Among these, the sol-gel technique offers many advantages over other techniques, such as high chemical homogeneity, fine grain structure, and low crystallization temperature, and by being both an economical and technically simple procedure to perform. $^{20,21}$

The objective of this study is to fabricate novel polyester urethane (PU)/nano fluor-hydroxyapatite (nFHA) porous composites processed by solid-liquid phase separation. The nFHA particles were dispersed uniformly in the polyurethane matrix to improve the mechanical properties and bioactivity. The miscibility, morphology, water uptake, and chemical and mechanical properties of the composite samples were investigated.

\section{Material and methods Materials}

1,6-Hexamethylene diisocyanate (HMDI) and 1,4-dioxane were purchased from Merck (Darmstadt, Germany). Polycaprolactone (PCL, $M_{n}=2,000$; Sigma. Aldrich St. Louis, MO) and 1,4-butanediol (BDO; Merck) were dried under vacuum for 48 hours to remove the residual water. Calcium nitrate $\left(\mathrm{Ca}\left(\mathrm{NO}_{3}\right)_{2}, 4 \mathrm{H}_{2} \mathrm{O}\right.$; Merck), ammonium fluoride $\left(\mathrm{NH}_{4} \mathrm{~F}\right.$; Merck), and triethyl phosphite (TEP, $\left(\mathrm{C}_{2} \mathrm{H}_{5} \mathrm{O}\right)_{3} \mathrm{P}$; Merck) were used for preparation of $n F H A$ particles.

\section{Synthesis of nFHA powder}

A mixture of FHA nanoparticles containing $50 \mathrm{wt} \% \mathrm{HA}$ and $50 \mathrm{wt} \%$ FA was synthesized via the sol-gel method. Calcium nitrate, TEP, and ammonium fluoride $\left(\mathrm{NH}_{4} \mathrm{~F}\right)$ were used as $\mathrm{Ca}, \mathrm{P}$, and $\mathrm{F}$ precursors, respectively. To prepare FHA nanopowders, TEP was first hydrolyzed in ethanol with a small amount of distilled water. The molar ratio of $\mathrm{OH}$ to $\mathrm{P}$ was kept at $1 / 6$. An appropriate amount of the ammonium fluoride powder was then added directly to TEP solution and stirred for 24 hours. To achieve a stoichiometric ratio of $\mathrm{Ca}$ to $\mathrm{P}$ equal to 1.67 , the appropriate amounts of TEP solution were added dropwise to the calcium nitrate solution. This solution was stirred for 1 hour and aged at $25^{\circ} \mathrm{C}$ for 24 hours and afterward at $40^{\circ} \mathrm{C}$ for 72 hours. ${ }^{22}$ The mixture was dried in a vacuum oven at $80^{\circ} \mathrm{C}$. Finally, the resulting powder samples were heated at $550^{\circ} \mathrm{C}$ for 1 hour in air.

\section{Synthesis of polyurethane}

The polyurethane was obtained in a 2 -step process. In the first step, the PCL and HMDI were mixed together, and the mixture was reacted at $80^{\circ} \mathrm{C}$ for 4 hours in a glass reactor under nitrogen atmosphere to produce a viscous prepolymer. A stoichiometry ratio of HMDI to PCL equal to 6:1 was taken into account. The excess of HMDI was distilled under reduced pressure at $80^{\circ} \mathrm{C}$ in the vacuum oven. In the second step, the prepolymer was reacted with $\mathrm{BDO}$ at $80^{\circ} \mathrm{C}$ for 30 minutes under nitrogen atmosphere. The polymer was immersed in distilled water. The resulting polymer was precipitated in $80 \%$ ethanol solution at $37^{\circ} \mathrm{C}$ for 48 hours to remove unreacted monomers. Finally, the polymer was dried under vacuum at $40^{\circ} \mathrm{C}$ for 24 hours.

\section{Fabrication of PU/nFHA composite foams}

Pure polyurethane (sample control) and nanocomposite foams containing 5, 10, and $20 \mathrm{wt} \%$ nFHA were prepared by solid-liquid phase separation and subsequent freezedrying. A solution of PU in dioxane with a volume ratio of $3 \%(\mathrm{w} / \mathrm{v})$ was prepared first. After homogeneous mixing of the solution for $24 \mathrm{~h}$, appropriate amounts of nFHA powders were added into the polyurethane solution. The mixture was stirred for 30 minutes and was rapidly cooled down to $-5^{\circ} \mathrm{C}$ afterwards. The samples were freeze-dried under vacuum $(0.1 \mathrm{mbar})$ for solvent sublimation. The porous samples were dried finally at room temperature in a vacuum oven at $40^{\circ} \mathrm{C}$ until reaching a constant weight. 


\section{Characterization of samples}

Fourier transform infrared (FTIR) spectrometer (Spectrum One; BOMEM- MB100-SERIES, USA) was used to characterize chemical structure of the samples. Phase compositions of nFHA were studied with X-ray diffraction (XRD-D4; SIEMENS, Bruker Co, Germany) with $\mathrm{CuK} \alpha$ radiation (wavelength $=1.54056 \AA$ ).

The size distribution and morphology of pure polyurethane foam, and PU/nFHA composite foam were characterized with transmission electron microscopy (TEM) using a Philips CM200 FEG (Field Emission Gun; Philips, Best, The Netherlands) transmission electron microscope operated at $200 \mathrm{kV}$.

The pore structure and morphology of polyurethane and PU/nFHA composite scaffolds were studied using scanning electron microscopy (SEM, LEO 440I; UK). The pore size of the porous samples was measured from the high-resolution SEM micrographs. Average pore size was calculated by measuring the size of 25 pores using the image analysis software. ${ }^{23}$

The compression tests were performed using an Instron tester model 1195 (Instron Corp, High Wycombe, UK). The cylindrical specimens, taken from scaffolds were examined at a crosshead speed of $2 \mathrm{~mm} / \mathrm{min}$ at $23 \pm 2^{\circ} \mathrm{C}$. All the given values are means of 6 measurements.

\section{Porosity of foam samples}

A liquid displacement method was used to measure the porosity of foam samples. Ethanol was used as the liquid because it did not induce any reaction or shrinkage, and it penetrated

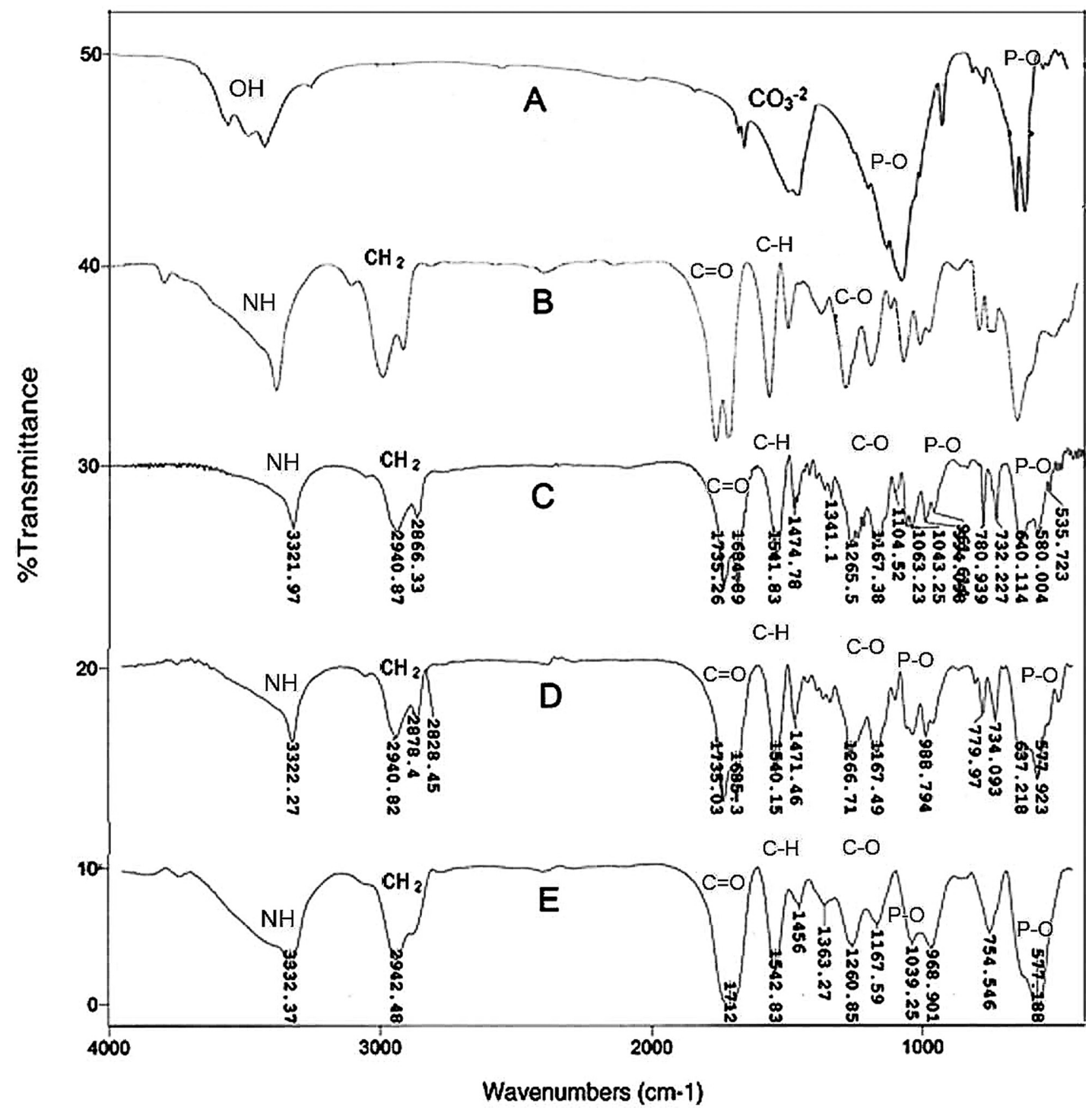

Figure I Infrared spectra of samples: A) FHA; B) PU-0\% FHA; C) PU-5\% FHA; D) PU-10\% FHA; E) PU-20\% FHA. Abbreviations: FHA, fluor-hydroxyapatite; PU, polyester urethane. 
A)

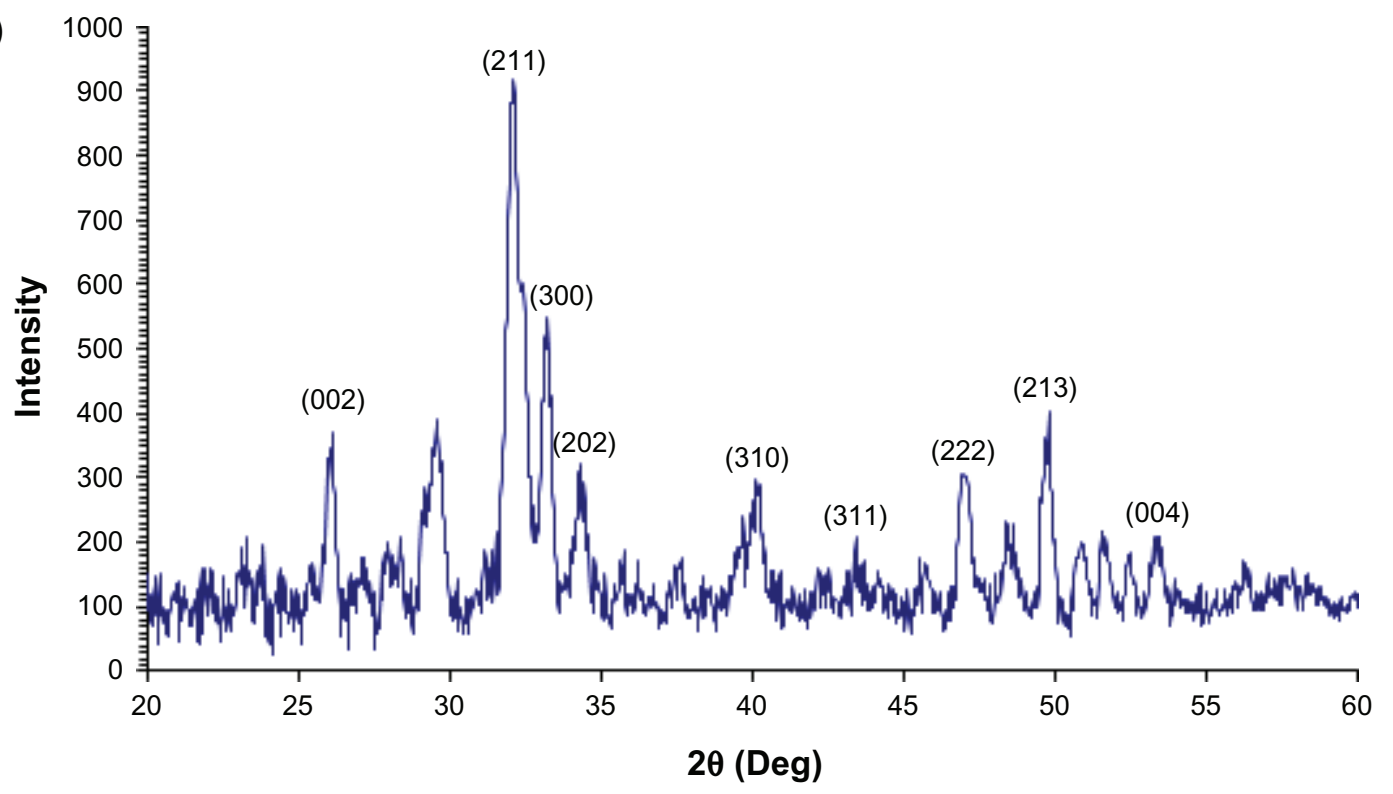

B)

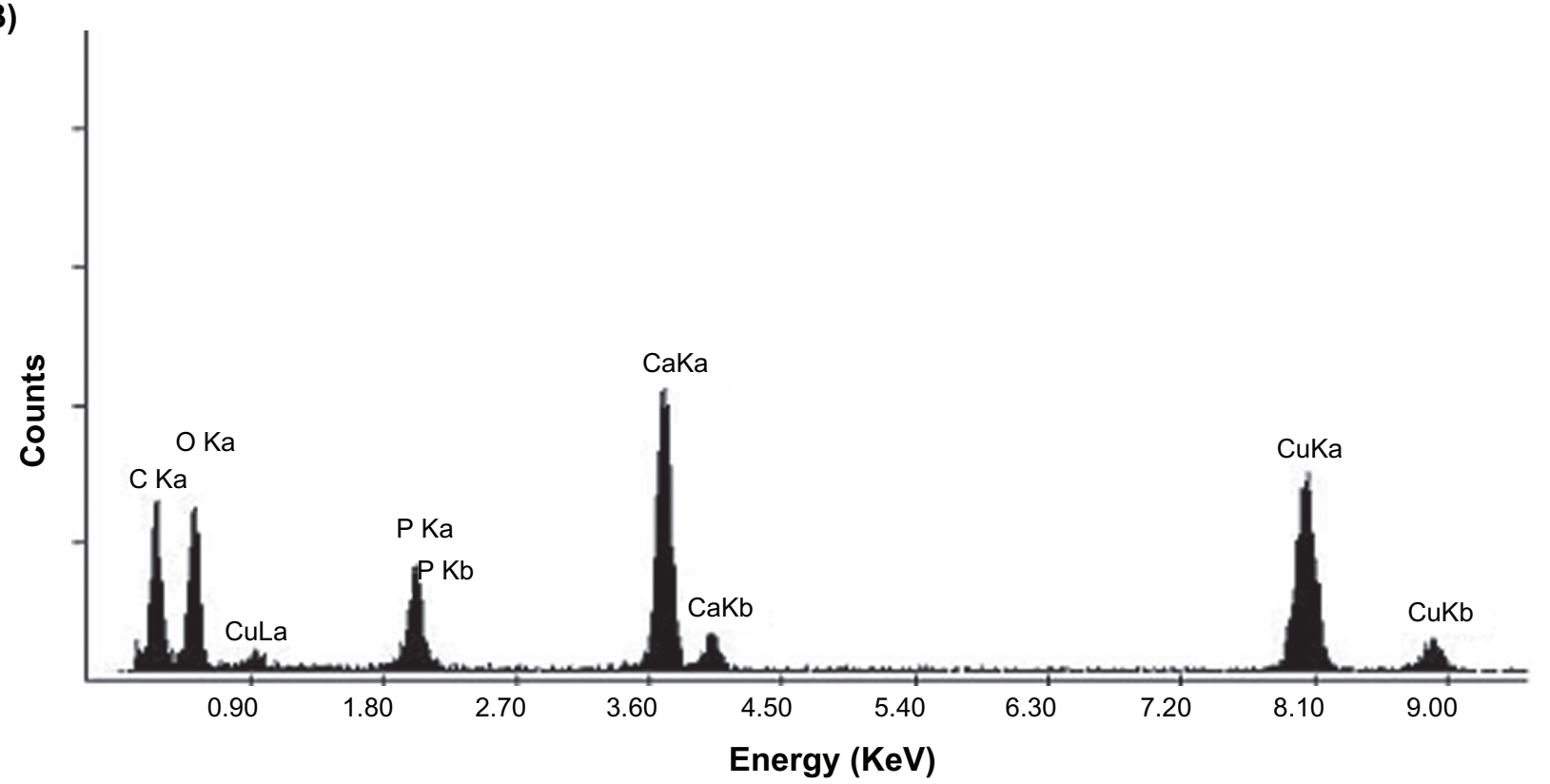

Figure 2 XRD pattern $\mathbf{A}$ ) and EDX B) of FHA nanoparticles.

Abbreviations: XRD, X-ray diffraction; EDX, energy dispersive X-ray spectroscopy; FHA, fluor-hydroxyapatite.

easily into the pores. A measured weight sample $(W)$ was immersed in a cylinder tube containing a known volume of ethanol $\left(V_{1}\right)$. The cylinder was placed in a vacuum to force the ethanol to penetrate entirely the pores. The total volume of ethanol containing the sample was recorded as $V_{2}$. The ethanol saturated scaffold was removed from the tube, and the residual ethanol volume was recorded as $V_{3}$. The relative porosity of the open pores in the scaffold $\varepsilon$ was expressed as reported by Zhang ${ }^{24}$ and Hsu et al ${ }^{25}$ (see following equation). ${ }^{26}$

$$
\mathcal{E}=\frac{\left(V_{1}-V_{2}\right)}{\left(V_{2}-V_{3}\right)}
$$

\section{Water uptake experiments}

All foam samples obtained in the study swelled in distilled water and were kept for 192 hours at $37^{\circ} \mathrm{C}$ in an incubator. Ratio of mass sample to water volume was 1:30. At the end of each predetermined time, the samples were removed from 

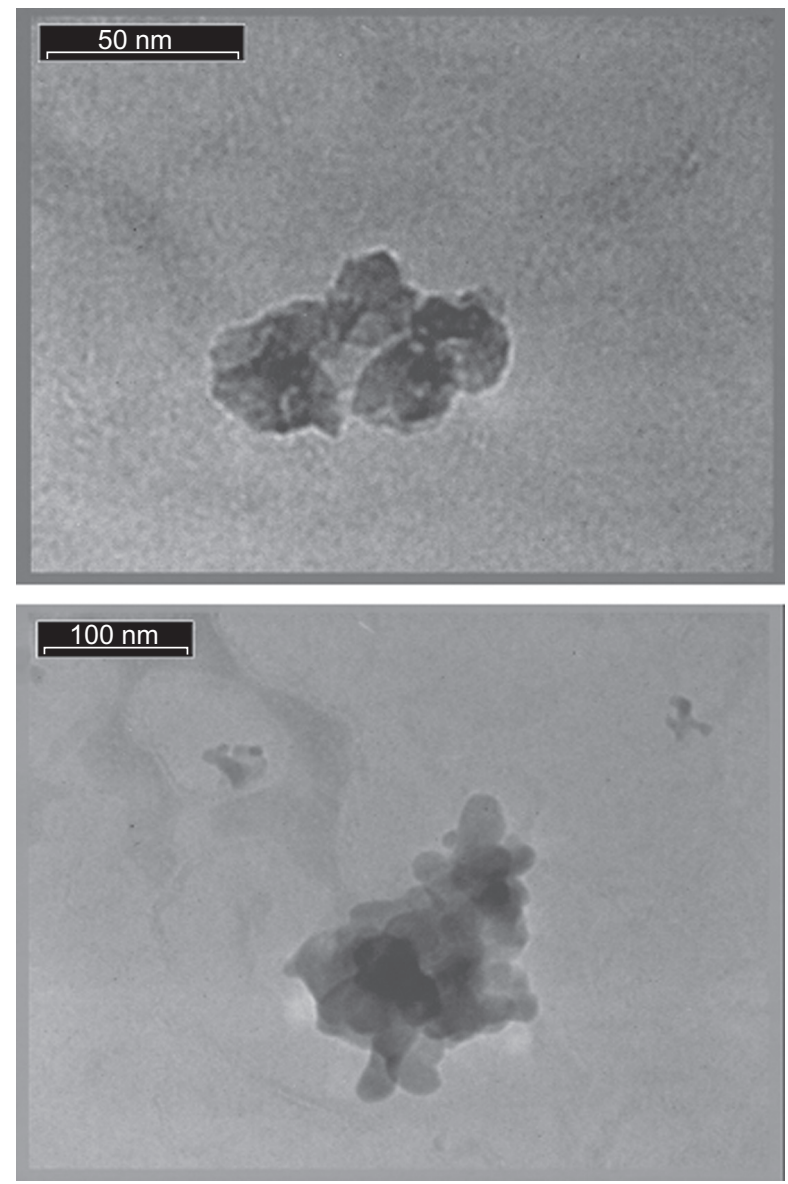

Figure 3 Bright field TEM image of FHA nanoparticles.

Abbreviations: FHA, fluor-hydroxyapatite; TEM, transmission electron microscopy.

the water, rinsed with distilled water, and finally weighed after wiping gently with filter paper to determine the water uptake. For each experiment, three replicates were used. The percentage of water uptake was calculated according to the following equation:

$$
\% \text { Water uptake }=\left(m_{2}-m_{1}\right) / \mathrm{m}_{1} \times 100
$$

where, $m_{1}$ standard $=$ dry sample; $m_{2}=$ wet sample. ${ }^{27}$

\section{Results and discussion Characterization of nFHA powder}

The results of FTIR and XRD revealed that a partial substitution of the $\mathrm{OH}^{-}$in $\mathrm{HA}^{-}$by $\mathrm{F}^{-}$occurred. The results of FTIR and XRD revealed that a partial substitution of the $\mathrm{OH}^{-}$in $\mathrm{HA}$ by $\mathrm{F}^{-}$occurred and the nanoparticles were composed of both HA and FA phases (Figures 1A and 2A). A considerable degree of crystallinity (78\%) was deduced from XRD patterns.

$\mathrm{A} \mathrm{Ca} / \mathrm{P}$ ratio of around 1.65 was estimated from energy dispersive $\mathrm{X}$-ray spectroscopy (EDX) through TEM analysis (Figure 2B). The particle size of powders evaluated by TEM

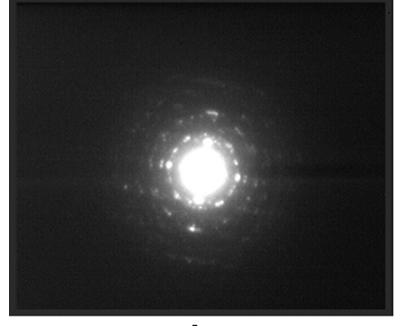

A

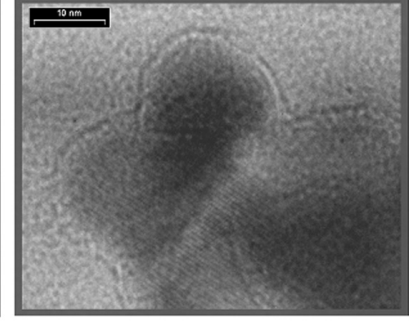

B
Figure 4 Diffraction pattern A) and Crystalline plane B) of FHA nanoparticles taken by TEM.

Abbreviations: FHA, fluor-hydroxyapatite; TEM, transmission electron microscopy

was less than $100 \mathrm{~nm}$ (Figure 3). In accordance with the results of XRD experiments, the diffraction pattern presented in Figure 4A revealed that the FHA nanoparticles were almost crystalline.

Crystalline planes of a nanoparticle can be observed in a very high resolution TEM image (Figure 4B). The crystallite size assessed directly from TEM imaging and estimated from XRD patterns using Scherrer equation were about $20-50 \mathrm{~nm}$ and $13 \mathrm{~nm}$, respectively.

\section{FTIR analysis}

The FTIR spectra of PU and nFHA/PU composite foam samples with different nFHA contents are shown in Figure 1. The absorption band at $3550 \mathrm{~cm}^{-1}$ is related to the vibration bending of hydroxyl (-OH) of nFHA (Figure 1A). The characteristic absorption band around $3322 \mathrm{~cm}^{-1}$ corresponds to hydrogen-bonded $\mathrm{NH}$ groups, and the sharp absorption bands related to asymmetric and symmetric $-\mathrm{CH}_{2}$ groups are observed at 2940 and $2866 \mathrm{~cm}^{-1}$, respectively. In addition, the strong bands at 1735 and $1684 \mathrm{~cm}^{-1}$ belong to the free and hydrogen-bonded $-\mathrm{C}=\mathrm{O}$ groups of PU. ${ }^{28,29}$ The bands in the range $1040-1220 \mathrm{~cm}^{-1}$ are related to vibration of $\mathrm{C}-\mathrm{O}$ and $\mathrm{C}-\mathrm{O}-\mathrm{C}$ groups. ${ }^{7,28,29}$ Disappearance of the isocyanate group's peak $\left(2270 \mathrm{~cm}^{-1}\right)$ revealed the fact that HMDI reacted well, and polymerization has been completed throughout the synthesis. Various modes of $-\mathrm{CH}_{2}$ vibrations are manifested in the range $1260-1465 \mathrm{~cm}^{-1}$.

In the synthesis of PU, the ratio of $\mathrm{NCO}$ to $\mathrm{OH}$ was $6: 1$. The $\mathrm{NCO}$ to $\mathrm{OH}$ ratio higher than 1.0 may result in the cross linking of polyurethane during the formation of allophanates and biurets. However, obvious bands owing to allophanates and biurets were not observed probably because the bands were weak or overlapped with other absorption bands. ${ }^{30}$

The peaks at 1460 and $1420 \mathrm{~cm}^{-1}$ are related to carbonic group $\left(\mathrm{CO}_{3}^{-2}\right)$ in nFHA, and the absorption bands at 567, 


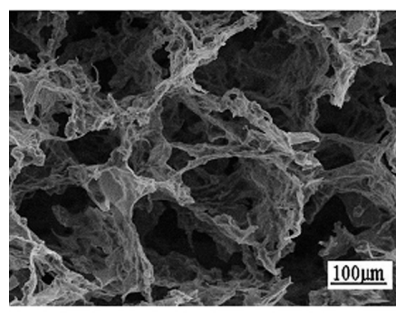

A

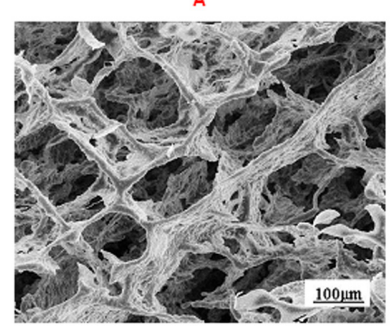

c
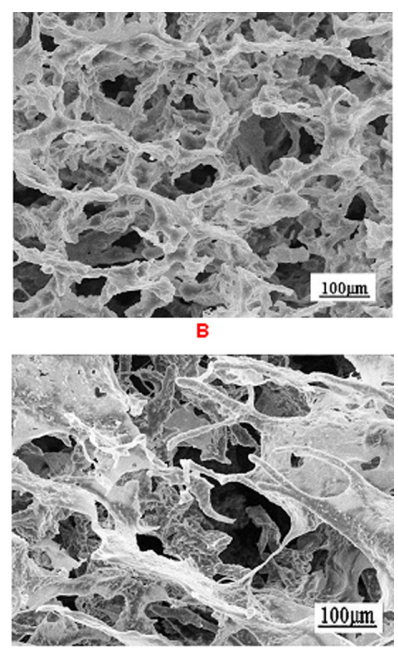

D
Figure 5 SEM images of nanocomposite scaffolds: A) PU-0\% FHA; B) PU-5\% FHA; C) PU-10\% FHA; D) PU-20\% FHA.

Abbreviations: SEM, scanning electron microscopy; PU, polyster urethane; FHA, fluor-hydroxyapatite.

1037, and $1091 \mathrm{~cm}^{-1}$ belong to phosphate groups $\left(\mathrm{PO}_{4}^{-3}\right)$, which shift to 580, 1039, and $1104 \mathrm{~cm}^{-1}$ (Figure 1C), to 578, 1039, and $1102 \mathrm{~cm}^{-1}$ (Figure 1D), and to 577, 1039, and $1102 \mathrm{~cm}^{-1}$ (Figure 1E), respectively. ${ }^{31,32}$

There are some molecular interactions between polyurethane and nFHA in the FTIR spectra. The hydroxyl group from FHA is thought to be able to easily link with the carboxyl or amino groups from PU. ${ }^{6}$ Disappearance of the peaks at $3550 \mathrm{~cm}^{-1}$ corresponding to - OH groups in nFHA might be attributed to chemical linkage between hydroxyl groups of nFHA and polyurethane groups. ${ }^{31}$ This disappearance could be affected by small amounts of nFHA (0-20 [w/w\%]) in composite samples and the substitution of $50 \% \mathrm{OH}^{-}$by $\mathrm{F}^{-}$in FHA nanoparticles. Also, it could be mentioned that polyurethane has linked with nFHA by hydrogen bonding. ${ }^{31}$

\section{SEM observation and porosity}

The microstructures of pure and nFHA/PU scaffold shown in Figure 5 revealed the presence of well-distributed macropores throughout the scaffolds and some micropores within the

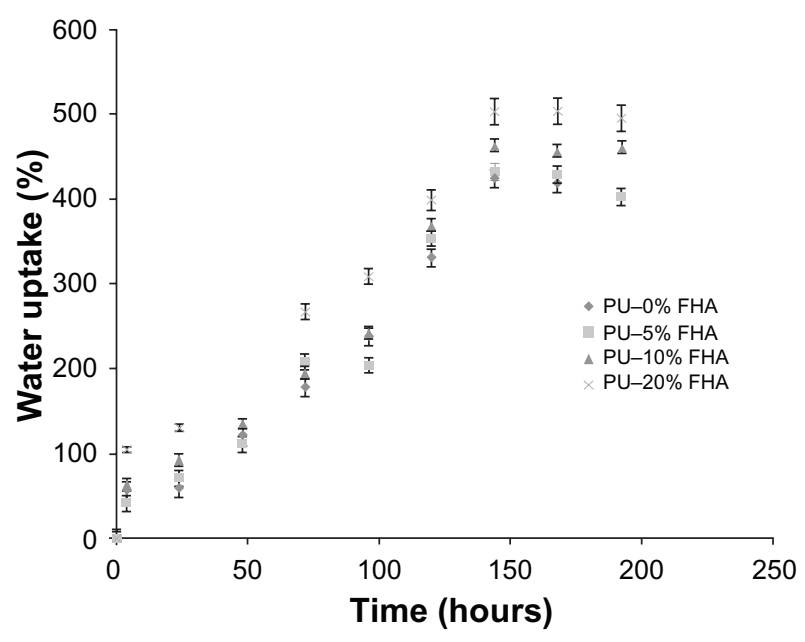

Figure 6 Water uptake percentage of scaffold samples with different contents of $n F H A$.

Abbreviation: nFHA, nano-fluor-hydroxyapatite.

pore walls. The size, morphology, and interconnectivity of pores determine the ability of the scaffolds to the nutrient diffusion, metabolic product delivery, cell attachment, tissue ingrowth, and angiogenesis. With the increase of mineral content, porosity and pore average size decreased, and wall thickness increased slightly. ${ }^{33}$ It seems that the closed pores are formed in the samples containing higher nFHA content. Moreover, the SEM images showed that nFHA powder homogeneously dispersed in the pore wall as well as in the pore surfaces. The porosity of pure PU and PU-20\% nFHA samples were approximately $88 \%$ and $80 \%$, respectively. The pores were regular, uniformly distributed, and interconnected with average pore sizes ranging 50-250 $\mu \mathrm{m}$, which are suitable scaffold architecture for application in bone tissue engineering. ${ }^{11,34}$

\section{Mechanical properties}

The mechanical properties of the PU and PU/nFHA composite foams are summarized in Table 1 . It can be deduced that by increasing nFHA content in the composite samples, the compressive strength and modulus increased. ${ }^{33,35}$ This increase can be attributed to both the hardness of nFHA

Table I Mechanical properties of the scaffolds

\begin{tabular}{|c|c|c|c|c|}
\hline Sample & $\begin{array}{l}\text { nFHA ratio } \\
(w / w) \%\end{array}$ & $\begin{array}{l}\text { Compressive } \\
\text { strength (KPa) }\end{array}$ & $\begin{array}{l}\text { Compressive } \\
\text { modulus (KPa) }\end{array}$ & Porosity $\varepsilon(\%)$ \\
\hline PU-0\% FHA & 0 & $240 \pm 9$ & $270 \pm 8$ & $87.7 \pm 1$ \\
\hline PU-5\% FHA & 5 & $360 \pm 6$ & $460 \pm 7$ & $86.0 \pm 3$ \\
\hline PU-10\% FHA & 10 & $520 \pm 6$ & $610 \pm 9$ & $84.7 \pm 2$ \\
\hline PU-20\% FHA & 20 & $610 \pm 9$ & $780 \pm 11$ & $79.9 \pm 2$ \\
\hline
\end{tabular}


particles, the adhesion between polyurethane and nFHA, and homodispersion of nFHA particles in the polyurethane matrix. The presence of a considerable porosity $(80 \%-88 \%)$ can be considered as a real cause for low compression modulus of composite samples. However, it should be noted that using an aromatic diisocyanate could lead to a higher compressive strength value of PU polymers.

\section{Water absorption}

The water uptake ability of the scaffolds was depended on the material's composition. Figure 6 shows that water uptake increased very quickly in the foam samples. The amount of absorbed water during incubation in water increases with the nFHA content. As seen in this figure, the most hydrophilic materials containing 20\% nFHA absorbed the highest amount of water. The composite scaffolds absorbed a very high amount of water in the range 424\%-502\% after 144 hours incubation in water (Figure 6). Water absorption after 6 days achieved a plateau value at the end of incubation period. The percentage of water absorption in all scaffold composites was higher than in the pure PU scaffolds during 192 hours. $^{36,37}$

\section{Conclusion}

A novel porous scaffold based on polyurethane and nFHA was fabricated in this study. Aliphatic polyurethane was polymerized with PCL diols as soft segment and HMDI and $\mathrm{BDO}$ as hard segment. A higher amount of HMDI compared with PCL diols $(\mathrm{NCO} / \mathrm{OH}=6 / 1)$ led to an important cross linking in the PU sample. The porous composites were obtained by solid-liquid phase separation and freeze drying. The SEM images indicated that the pores were interconnected and uniformly distributed. The porous scaffolds not only have pores with sizes in the range 50-250 $\mu \mathrm{m}$ but also contain many micropores in the scaffold wall. In the FTIR spectra, it was shown that nFHA particles formed hydrogen bonds with the polyurethane. The compressive strength and compressive modulus of polyester polyurethane scaffolds increased with increasing nFHA powder ratio. When the nFHA content changed from $0 \mathrm{wt} \%$ to $20 \mathrm{wt} \%$, the samples showed suitable mechanical properties and a high porosity of 80 to $88 \%$. These novel nFHA/PU scaffolds have potential for bone regeneration, and may be suitable for use as a scaffold for applications in bone tissue engineering.

\section{Acknowledgments}

The authors would like to thank the Science and Research Branch of Islamic Azad University for financial support of this research. The authors wish to thank Ms Sima Eshghi for SEM studies.

\section{Disclosure}

The authors report no conflicts of interest in this work.

\section{Referenes}

1. Greenwald AS, Boden SD, Goldberg VM, Khan Y, Laurencin CT, Rosier RN. Bone-graft substitutes: facts, fictions, and applications. J Bone Joint Surg Am. 2001;83A:98-103.

2. Yang F, Wolke JGC, Jansen JA. Biomimetic calcium phosphate coating on electrospun poly ( $\varepsilon$-caprolactone) scaffolds for bone tissue engineering. Chem Eng J. 2008;137:154-161.

3. Lu HH, Tang A, Cheol OhS, Spalazzi JP, Dionisio K. Compositional effects on the formation of a calcium phosphate layer and the response of osteoblast-like cells on polymer-bioactive glass composites. Biomaterials. 2005;26:6323-6334.

4. Rezwan K, Chen QZ, Blaker JJ, Boccaccini AR. Biodegradable and bioactive porous polymer/inorganic composite scaffolds for bone tissue engineering. Biomaterials. 2006;27:3413-3431.

5. Hill CM, An YH, Kang QK, Hartsock LA, Gogolewski S, Gorna K. Osteogenesis of osteoblast seeded polyurethane-hydroxyapatite scaffolds in nude Mice. Macromol Symp. 2007;253:94-97.

6. Huang MN, Wang YL, Luo YF. Biodegradable and bioactive porous polyurethanes scaffolds for bone tissue engineering. J Biomed Sci Eng. 2009;2:36-40

7. Bil M, Ryszkowska J, Roether JA, Bretcanu O, Boccaccini AR. Bioactivity of polyurethane-based scaffolds coated with Bioglass. Biomed Mater. 2007;2(2):93-101.

8. Chetty A, Steynberg T. Hydroxyapatite-coated polyurethane for auricular cartilage replacement: an in vitro study. J Biomed Mater Res A. 2008; 84(2):475-482.

9. Huang X, Miao X. Novel porous hydroxyapatite prepared by combining $\mathrm{H}_{2} \mathrm{O}$ foaming with PU sponge and modified with PLGA and bioactive glass. J Biomater Appl. 2007;21(4):351-374.

10. Brovarone $C V$, Verne E. Development of glass ceramic scaffolds for bone tissue engineering: characterization, proliferation of human osteoblasts and nodule formation. Acta Biomater. 2007;3:199-208.

11. Mathieu LM, Mueller TL, Bourban PE, Pioletti DP, Muller R, Manson JAE. Architecture and properties of anisotropic polymer composite scaffolds for bone tissue engineering. Biomaterials. 2006;27: 905-916.

12. Liu DM, Troczynski T, Tseng WJ. Water-based sol-gel synthesis of hydroxyapatite: process development. Biomaterials. 2001; 22:21-30.

13. Kui C, Ge S, Wenjian W, et al. Synthesis of hydroxyapatite/ fluoroapatite solid solution by a sol-gel method. Mater Lett. 2001;51: $37-41$.

14. Jha LJ, Best SM, Knowles JC, Rehman I, Santos JD, Bonfield N. Preparation and characterization of fluoride-substituted apatites. J Mater Sci Mater Med. 1997;8:91-185.

15. Elliott JC. Structure and Chemistry of the Apatites and Other Calcium Orthophosphates. Amsterdam, The Netherlands: Elsevier Science; 1994.

16. Aoba T. The effect of fluoride on apatite structure and growth. Crit Rev Oral Biol Med. 1997;8:136-153.

17. Stan GE, Ferreira JMF. An algorithm for preparing bioactive fluorinated hydroxyapatite coatings by sol gel technique. J Optoelectron Adv Mater. 2007;9(8):2539-2542.

18. Miao S, Weng W, Cheng K, et al. In vitro bioactivity and osteoblast-like cell test of zinc containing fluoridated hydroxyapatite films. $J$ Mater Sci Mater Med. 2007;18:2101-2105.

19. Slosarczyk A, Stobierska E, Paszkiewicz Z, Gawlick M. Calcium phosphate materials prepared from precipitates with various calcium phosphorus molar ratios. J Am Ceram Soc. 1996;79(10):2539-2544.

20. Liu DM, Yang Q, Troczynski T, Tseng WJ. Structural evolution of solgel-derived hydroxyapatite. Biomaterials. 2002;23:1679-1687.

21. Weng W, Baptista JL. Sol-gel derived porous hydroxyapatite coatings. J Mater Sci Mater Med. 1998;9:159-163. 
22. Kim HW, Kong YM, Bae CJ, Noh YJ, Kim HE. Sol-gel derived fluor-hydroxyapatite biocoatings on zirconia substrate. Biomaterials. 2004;25:2919-2926.

23. Lim YM, Gwon HJ, Choi JH, Shin J, Nho YC. Preparation and biocompatibility study of gelatin/kappa-carrageenan scaffolds. Macromol Res. 2010;18(1):29-34.

24. Zhang RY, Ma PX. Poly (alpha-hydroxyl acids)/hydroxyapatite porous composites for bone-tissue engineering. I. Preparation and morphology. J Biomed Mater Res. 1999;44:446-455.

25. Hsu YY, Gresser JD, Trantolo DJ, Lyons CM, Gangadharam PR, Wise DL. Effect of polymer foam morphology and density on kinetics of in vitro controlled release of isoniazid from compressed foam matrices. J Biomed Mater Res. 1997;35:107-116.

26. Guan J, Fujimoto KL, Sacks MS, Wagner WR. Preparation and characterization of highly porous, biodegradable polyurethane scaffolds for soft tissue applications. Biomaterials. 2005;26:3961-3971.

27. Gorna K, Gogolewski S. In vitro degradation of novel medical biodegradable aliphatic polyurethanes based on $\varepsilon$-caprolactone and Pluronics with various hydrophilicities. Polym Degrad Stab. 2002;75:113-122.

28. McCarthy SJ, Mejis GF, Mitchell N, et al. In-vivo degradation of polyurethanes: transmission-FTIR microscopic characterization of polyurethanes sectioned by cryomicrotomy. Biomaterials. 1997; 18:1387-1409.

29. Gorna K, Polowinski S, Gogolewski S. Synthesis and characterization of biodegradable poly ( $\varepsilon$-caprolactone urethane)s. I. Effect of the polyol molecular weight, catalyst, and chain extender on the molecular and physical characteristics. J Polym Sci A Polym Chem. 2002;40:156-170.
30. Kurimoto Y, Takeda M, Doi S, Tamura Y, Ono H. Network structures and thermal properties of polyurethane films prepared from liquefied wood. Bioresour Technol. 2001;77:33-40.

31. Wang L, Li Y, Zuo Y, et al. Porous bioactive scaffold of aliphatic polyurethane and hydroxyapatite for tissue regeneration. Biomed Mater. 2009;4(2):025003.

32. Dong Z, Li Y, Zou Q. Degradation and biocompatibility of porous nano-hydroxyapatite/polyurethane composite scaffold for bone tissue engineering. Appl Surf Sci. 2009;255:6087-6091.

33. Boissard CIR, Bourban PE, Tami AE, Alini M, Eglin D. Nanohydroxyapatite/poly(ester urethane) scaffold for bone tissue engineering. Acta Biomater. 2009;5:3316-3327.

34. Pineda LM, Busing M, Meinig RP, Gogolewski S. Bone regeneration with resorbable polymeric membranes. III. Effect of poly (L-lactide) membrane pore size on the bone healing process in large defects. J Biomed Mater Res. 1996;31:385-394.

35. Baino F, Verne E, Brovarone CV. Feasibility, tailoring, and properties of polyurethane/bioactive glass composite scaffolds for tissue engineering. J Mater Sci Mater Med. 2009;20:2189-2195.

36. Gorna K, Gogolewski S. Preparation, degradation, and calcification of biodegradable polyurethane foams for bone graft substitutes. J Biomed Mater Res A. 2003;67(3):813-827.

37. Maquet V, Boccaccini AR, Pravata L, Notingher I, Jerome R. Porous poly (a-hydroxyacid)/bioglasss composite scaffolds for bone tissue engineering. I: preparation and in vitro characterization. Biomaterials. 2004;25:4185-4194.
International Journal of Nanomedicine

\section{Publish your work in this journal}

The International Journal of Nanomedicine is an international, peerreviewed journal focusing on the application of nanotechnology in diagnostics, therapeutics, and drug delivery systems throughout the biomedical field. This journal is indexed on PubMed Central, MedLine, CAS, SciSearch $\AA$, Current Contents ${ } /$ Clinical Medicine,

\section{Dovepress}

Journal Citation Reports/Science Edition, EMBase, Scopus and the Elsevier Bibliographic databases. The manuscript management system is completely online and includes a very quick and fair peer-review system, which is all easy to use. Visit http://www.dovepress.com/ testimonials.php to read real quotes from published authors. 